\title{
Studies of chemical emasculation in pepper. I.
}

\author{
Suppression of anther dehiscence and other morphological \\ changes caused by sodium 2,2-dichloropropionate \\ Tadahiko Hirose \\ Faculty of Agriculture, Kagawa University, Miki-cho, Kagawa.
}

\begin{abstract}
Summary
In an attempt to eliminate the trouble of hand emasculation from the hybridization work in pepper, possibility of emasculation with a gametocide was examined. Mie Midori, a cultivar of sweet pepper, was used in this experiment. Anther dehiscence was completely suppressed by foliage spray of 250 and $1250 \mathrm{ppm}$ aqueous solutions of sodium 2, 2-dichloropropionate (Dalapon). Suppression of anther dehis-

cence started about two weeks after treatment. Toxic effects to foliage and to plant growth were not severe while abnormal expansion of ovaries and bending of styles were accompanied with the suppression of anther dehiscence in a considerable number of flowers. The implications of these functional and morphological changes for hybrid seed production are discussed.
\end{abstract}

\section{Introduction}

Recently heterosis has been increasingly utilized for agricultural production. Above all, it has become the most important means for breeding procedure of vegetable crops. Besides solanaceous, cucurbitaceous and cruciferous vegetables for which a practical use of $F_{1}$ hybrid has been established, hybrid seed production has been opened on a commercial basis even in onion and carrot by making use of their male sterile lines. On the other hand, in almost all fruit-vegetables, such as tomato, eggplant, pepper, squash, muskmelon, cucumber and limabean, the utilization of their genetical male sterile lines for hybridization has not yet been commercialiy successful, although male sterile lines have been found in all of them ${ }^{(1,2,6,9,15,16,18,19)}$ The principal reason why the male sterile lines of these vegetables have not been used is that their products are the reproductive organs themselves.

In some species, the pepper plant for example, genetical male sterility results from the coexistence of male sterile gene or genes and male sterile cytoplasm. In this case, while the male sterile line is easily maintained, pollen parents to be used are strictly limited because there are very few varieties which have a restorer gene in them ${ }^{(5)}$. In another type of male sterility which has been found in tomato, sterility is caused by a pair of single recessive genes. In this case, it is required that the sterility forms a linis with another indicating factor in order to distinguish male sterile individuals from normal plants during the young stage. In addition, a great deal of labor and time is required to introduce these male sterile genes or restorer genes into most varieties.

In an attempt to reduce this trouble, irradiation by X-ray, gamma ray or thermoneutron has been employed to induce male sterile mutation in some vegetable crops ${ }^{(11)}$. However, the

The author wishes to express his appreciation to Dr. Y. TSUKAMoTo, Professor of Kyoto University, and Dr.S. TAKashima, Professor of Kyoto Prefectural University, for kindly revising the manuscript, and to Mr. E. FuSHō for his technical assistance.

Received for publication August 26, 1968 
difficulty of maintaining sterile lines is not removed even though a large number of male sterile mutants are made by irradiation. Moreover, these irradiations might bring about undesirable mutation in radiated plants.

In order to eliminate all of these troubles an induction of temporary male sterility through the use of several chemicals has been tested. Alphanaphthaleneacetic acid,2,4-dichlorophenoxyacetic acid, 2,3,5-triiodobenzoic acid and maleic hydrazide were examined first by REнM ${ }^{17)}$, Wittuer and Hillyer ${ }^{22)}$ and Nakamura ${ }^{13,14)}$ to discover whether they could be used as chemical gametocides or not. Recently, sodium alpha, beta-dichloroisobutyrate (DCIB) was developed as a selective gametocine and tested in the cotton plant ${ }^{(3)}$, watermelon ${ }^{(4)}$, tomato $^{(12)}$, papaya $^{(8)}$, cantaloupe ${ }^{(10)}$ and many other crops. Strangely enough, the effect of this chemical was considerably different in each species. In addition to this, sodium 2,2-dichloro propionate (Dalapon) and some other related compounds were also tested by Scotr ${ }^{(20,21)}$ and $\mathrm{KHo}_{\text {Ho }}$ DE BRUYN ${ }^{(7)}$.

Compared with tomato, eggplant and cucurbitaceous vegetables the pepper plant has many disadvantages as far as producing hybrid seed is concerned. The pepper plant has a comparatively small number of seeds, a highly changeable anther-dehiscent hour, rapid decrease in pollen activity and some other unfavorable characteristics with regard to hand pollination which make this species the most difficult one to use for the production of hybrid seed among the fruit-vegetables mentioned above. However, as the flowers of pepper are visited by a large number of insects, hand pollination can be eliminated by planting the mother parent variety mixed with the pollen parent variety if the application of a gametocide is efficient ${ }^{(5)}$. Therefore, pepper is one of the crops for which the practical use of chemical emasculation is desirable. In the present study, from the point of view mentioned above, growth and morphological changes in the pepper plant caused hy Dalapon were recorded.

\section{Materials and Methods}

Mie Midori, a cultivar of sweet pepper (Capsicum annuum L.) was used in this experiment. The seeds were sown on February 10th in 1967, and young plants were transplanted to a polyethylene house. Foliage spray was begun on May 27th with 20 milliliters of aqueous solution per plant containing 10,50, 250 or 1250 milligrams of sodium 2,2-dichloropropionate (Dalapon) per liter. None of wetting agents was contained in these solutions. Half of the plants were sprayed twice again with 30 milliliters of the same solutions per plant at intervals of a week. The experiment had a randomized biock design with four replications. Length of the style and diameters of the corolla, of the anther and of the ovary were recorded using callipers. In this report, the name of each treatment is abbriviated. For instance, three weekly applications of $250 \mathrm{ppm}$ of Dalapon are refered to as $250-3$, and so forth.

\section{Results}

Injury to foliage: Features of the plants three weeks after the beginning of application are shown in Fig. 1. No toxic effect was observed in 10-1, 10-3, 50-3 and 250-1. Even in 250-3 and 1250-1 only slight crinkling and chlorosis of the leaves were noticed. But a considerable amount of contact burn and a remarkable crinkling of leaves and severe distortion, chlorosis 


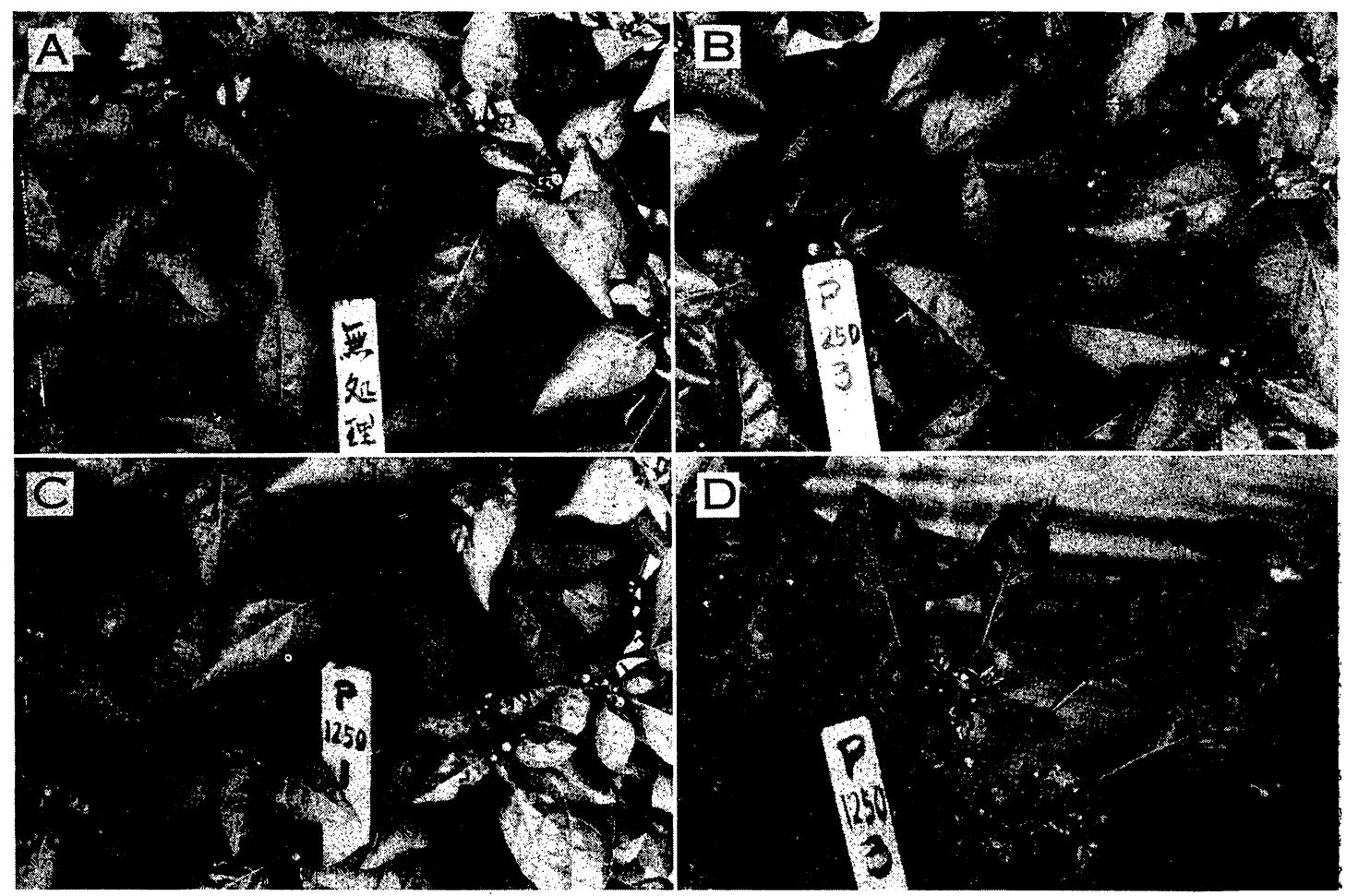

Fig. 1. Phytotoxity symptoms brought about by aqueous solutions of Dalapon three weeks after the beginning of treatment. A : Non-treated, B : Three weekly applications of $250 \mathrm{ppm}$, C : Single application of $1250 \mathrm{ppm}$ and D : Three weekly applications of $1250 \mathrm{ppm}$.

and partial killing of terminal buds were brought about by 1250-3.

Influence on growth: With regard to increase of plant height, there were no distinct differences among the plants treated with different concentrations except for 1250-3 by which the growth was inhibited just after the treatment. Increase of plant height after treatment is shown in Fig. 2 and Fig. 3. Furthermore, changes in the number of flowers after treatment are shown in Fig. 4 and Fig. 5. The pattern of changes after a single application is similar to that of the non-treated except for 1250-1 in which case the number of flowers decreased to such a marked extent that only one third of the number produced by the non-treated could

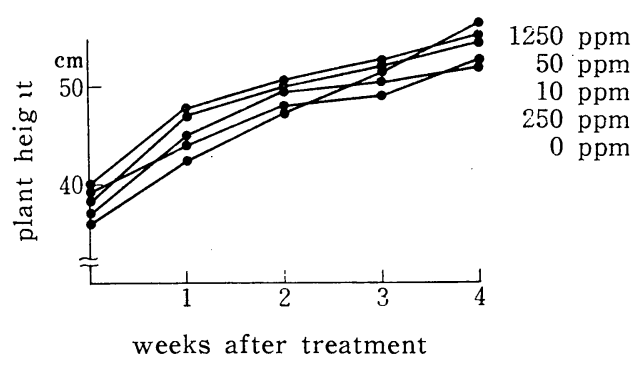

Fig. 2. Changes in plant height after treatment with Dalapon. (Single application)

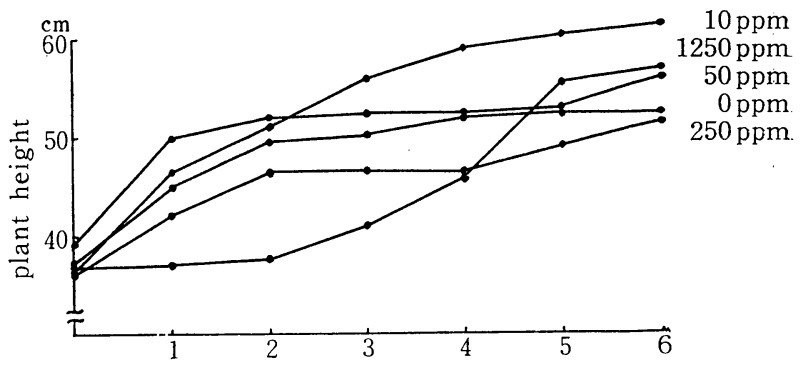

weeks after the beginning of treatment

Fig. 3. Changes in plant height after the beginning of treatment with Dalapon. (Three weekly applications) 


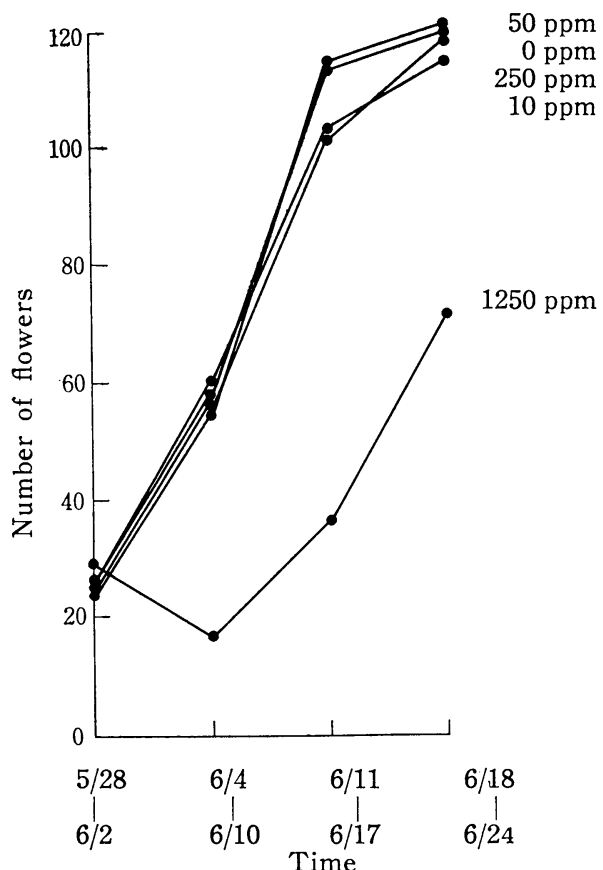

Fig. 4. Changes in the number of flowers per week after treatment with Dalapon. (Single application)

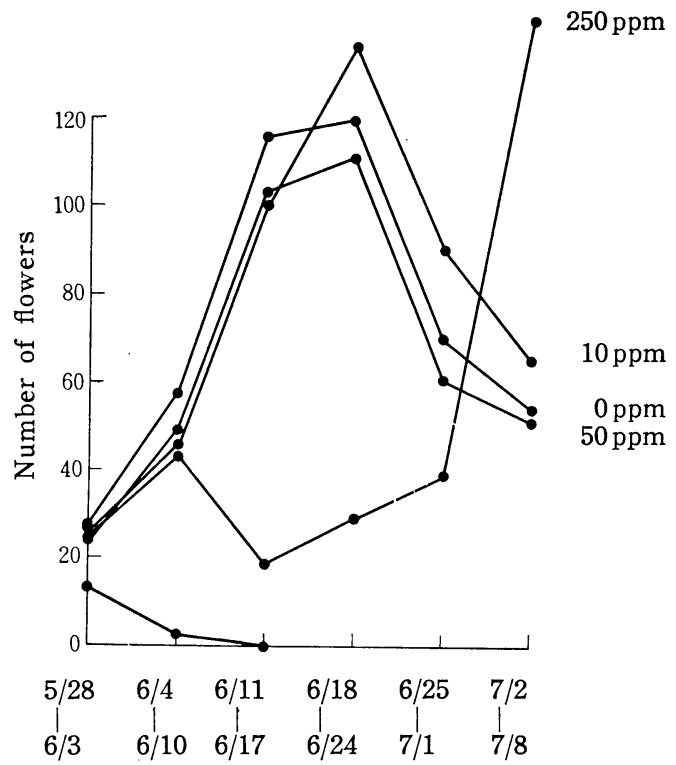

Fig. 5. Changes in the number of flowers per week after the beginning of treatment with Dalapon. (Three weekly applications)

be found on the treated plants during the second week. The number of flowers was not affected by application at low concentrations even after three weekly applications. The number of flowers produced by plants sprayed with high concentrations of Dalapon was much less than that of those sprayed with low concentrations during the five weeks following the treatment and then the number increased abruptly in 250-3 while flower formation was completely suppressed in 1250-3.

Suppressive effect on anther dehiscence: Non-treated and Dalapon-treated flowers are shown in Fig. 6. Although the anthers of non-treated flowers and flowers treated at 10 and $50 \mathrm{ppm}$ were purplish blue and dehisced normally, the anthers in 250-1 turned almost light
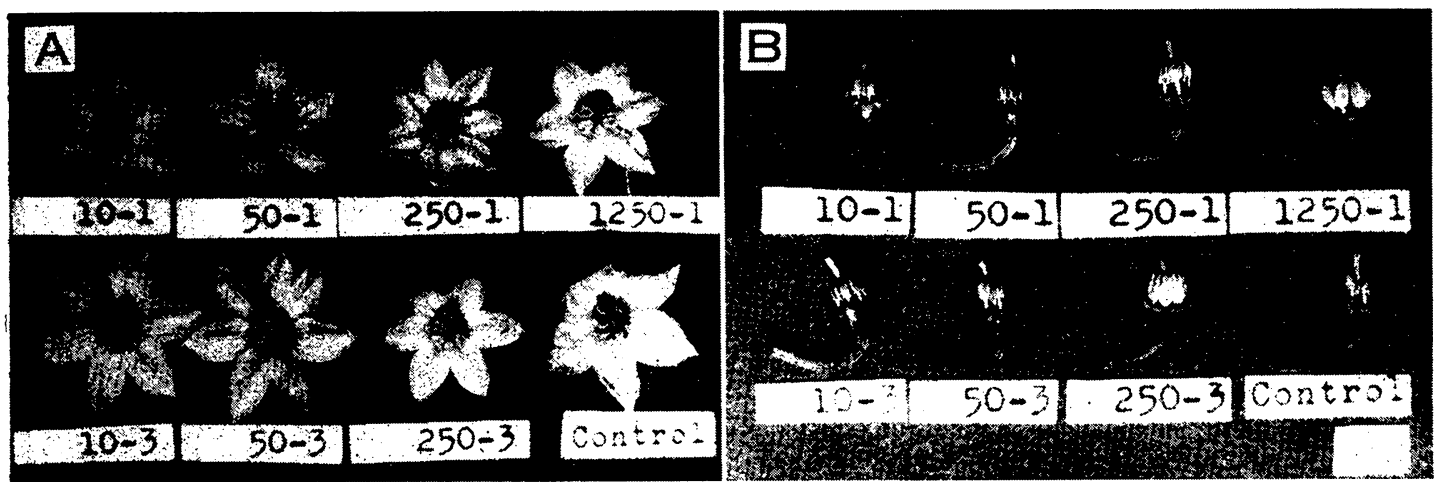

Fig. 6. Representative flowers from non-treated and Dalapon treated individuals three weeks after the beginning of treatment. A : Upper view and B : Side view without corollas. 
yellow and their dehiscence was suppressed by the treatment. Furthermore, in 250-3 and 1250-1, the anthers became light yellow and the dehiscence was completely inhibited. This suppression of anther dehiscence and color change began at about two weeks after treatment.

Morphological changes of floral organs: Dimensions of several floral organs measured at two weeks after the beginning of the application are shown in Table 1. As far as the diameter

Table 1. The influence of Dalapon foliage spray on the dimensions of several floral organs of the pepper plant two weeks after the beginning of treatment.

\begin{tabular}{|c|c|c|c|c|c|}
\hline $\begin{array}{l}\text { Concentration } \\
\text { ppm }\end{array}$ & $\begin{array}{c}\text { Number of } \\
\text { times sprayed }\end{array}$ & $\begin{array}{l}\text { Diameter of } \\
\text { corolla } \\
\mathrm{mm}\end{array}$ & $\begin{array}{c}\text { Transverse diameter } \\
\text { of anther } \\
\mathrm{mm}\end{array}$ & $\begin{array}{l}\text { Length of } \\
\text { style } \\
\mathrm{mm}\end{array}$ & $\begin{array}{c}\text { Transverse diameter } \\
\text { of ovary } \\
\mathrm{mm}\end{array}$ \\
\hline 0 & - & 21.2 & 1.5 & 5.1 & 3.2 \\
\hline $\begin{array}{r}10 \\
50 \\
250 \\
1250\end{array}$ & $\begin{array}{l}1 \\
1 \\
1 \\
1\end{array}$ & $\begin{array}{l}21.1 \\
20.7 \\
21.0 \\
20.0\end{array}$ & $\begin{array}{l}1.4 \\
1.7 \\
1.7 \\
1.6\end{array}$ & $\begin{array}{l}5.0 \\
5.8 \\
5.2 \\
5.2\end{array}$ & $\begin{array}{l}2.9 \\
2.8 \\
3.1 \\
3.9\end{array}$ \\
\hline $\begin{array}{r}10 \\
50 \\
250 \\
1250\end{array}$ & $\begin{array}{l}3 \\
3 \\
3 \\
3\end{array}$ & $\begin{array}{l}22.2 \\
21.1 \\
21.7 \\
-\end{array}$ & $\begin{array}{l}1.5 \\
1.5 \\
1.5 \\
-\end{array}$ & $\begin{array}{l}5.6 \\
5.6 \\
5.8 \\
-\end{array}$ & $\begin{array}{l}3.1 \\
3.0 \\
3.3 \\
-\end{array}$ \\
\hline $\begin{array}{l}5 \% \cdots \\
1 \%\end{array}$ & … & $\begin{array}{l}\text { N S } \\
\text { N S }\end{array}$ & $\begin{array}{l}\text { N S } \\
\text { N S }\end{array}$ & $\begin{array}{l}\text { N S } \\
\text { N S }\end{array}$ & $\begin{array}{l}0.4 \\
0.5\end{array}$ \\
\hline
\end{tabular}

of the corolla, the transverse diameter of the anther and the length of the style are concerned there are no statistically significant differences betweee non-treated and any given treated individuals. On the other hand, ovary diameter in 1250-1 is greater than those of the others and significant differences are noticeable between them. A tendency towards the production of larger ovaries was generally found whenever the higher concentration was used. When floral organs were measured two weeks later, the data showed almost the same result Table 2). The ovaries of 1250-1 and 250-3 were markedly larger than the others. The length

Table 2. The influence of Dalapon foliage spray on the dimensions of several floral organs of the pepper plant four weeks after the beginning of treatment.

\begin{tabular}{|c|c|c|c|c|c|}
\hline $\begin{array}{l}\text { Concentration } \\
\text { ppm }\end{array}$ & $\begin{array}{l}\text { Number of } \\
\text { times sprayed }\end{array}$ & $\begin{array}{l}\text { Diameter of } \\
\text { corolla } \\
\mathrm{mm}\end{array}$ & $\begin{array}{c}\text { Transverse diameter } \\
\text { of anther } \\
\mathrm{mm}\end{array}$ & $\begin{array}{l}\text { Length of } \\
\text { style } \\
\text { mm }\end{array}$ & $\begin{array}{c}\text { Transverse diameter } \\
\text { of ovary } \\
\mathrm{mm}\end{array}$ \\
\hline 0 & - & 19.4 & 1.5 & 5.6 & 2.3 \\
\hline $\begin{array}{r}10 \\
50 \\
250 \\
1250\end{array}$ & $\begin{array}{l}1 \\
1 \\
1 \\
1\end{array}$ & $\begin{array}{l}19.2 \\
20.5 \\
18.4 \\
21.1\end{array}$ & $\begin{array}{l}1.3 \\
1.4 \\
1.4 \\
1.6\end{array}$ & $\begin{array}{l}5.3 \\
5.4 \\
5.2 \\
5.1\end{array}$ & $\begin{array}{l}2.2 \\
2.3 \\
2.2 \\
3.1\end{array}$ \\
\hline $\begin{array}{r}10 \\
50 \\
250 \\
1250\end{array}$ & $\begin{array}{l}3 \\
3 \\
3 \\
3\end{array}$ & $\begin{array}{l}19.3 \\
20.4 \\
20.5 \\
-\end{array}$ & $\begin{array}{l}1.5 \\
1.5 \\
1.6 \\
-\end{array}$ & $\begin{array}{l}5.3 \\
5.9 \\
5.4 \\
-\end{array}$ & $\begin{array}{l}2.6 \\
2.6 \\
3.1 \\
-\end{array}$ \\
\hline $\begin{array}{ll}\text { LSD } & 5 \% \cdots \\
1 \% \cdots\end{array}$ & … & $\begin{array}{l}\text { N S } \\
\text { N S }\end{array}$ & $\begin{array}{l}\text { N S } \\
\text { N S }\end{array}$ & $\begin{array}{l}\mathrm{N} \mathrm{S} \\
\mathrm{NS}\end{array}$ & $\begin{array}{l}0.4 \\
0.6\end{array}$ \\
\hline
\end{tabular}

of the style was not affected by Dalapon, but, in 250-3 and 1250-1 it was observed that a considerable number of flowers in which the anther dehiscence was completely inhibited had bent styles as shown in Fig. 6. 


\section{Discussion}

Dalapon was first developed as a herbicide. Since the gametocidal action of this chemical was found, its utilization for hybrid seed production has been examined and discussed. Scotт ${ }^{20)}$ made an attempt to use it for producing hybrid cotton seed. KHo and [E BRUYN ${ }^{7)}$ sprayed snapdragon with it. LANGE $^{(8)}$ reported that sex expression of papaya was changed by using Dalapon.

Generally speaking, DCIB is more conmonly known than Dalapon as a chemical gemetocide and a number of experimental results with DCIB have been reported as mentioned in the introduction. According to those reports, however, the effects of DCIB seem to be considerably different among the species used, and opinions on the practical use of this gametocide have been divided even with regard to the same crop. The effect of DCIB on the pepper plant was tested by the present author and the practical use of this chemical was questioned in his former report ${ }^{(5)}$ because of the severe injury it inflicted on pepper leaves.

Visible injury to foliage caused by Dalapon was much less than by DCIB in the pepper plant. Even in 250-3 or 1250-1 the foliage was not injured severely while the purplish blue color of the anthers disappeared and its dehiscence was completely suppressed. In these anthers a considerable number of normally matured pollen grains were observed. Therefore, pollen formation seems not to be affected by Dalapon. Judging from the fact that the effect on the anthers started about two weeks after treatment, it is believed that Dalapon has no effect on flower-buds in which the reduction division of PMC has already taken place but affects younger flower-buds which are in the pre-meiosis stage, because the meiosis of PMC usually occurs 12 15 days before the anthesis in pepper flower-buds. Decrease in the number of flowers caused by the application of high concentration spray means that Dalapon retards the growth of the pepper plant. This decrease, however, may not be so serious a problem if it does not go to an extreme because no early yield is required for producing hybrid seeds. More puzzling problems are found in abnormally enlarged ovaries and bent styles. These morphological abnormalities of pistils may result in unfruitfulness or less seed setting.

\section{Literature cited}

1. Allard, R. W. 1953. A gene in lima beans pleiotropically affecting male-sterility and seedling abnormality. Proc. Amer. Soc. Hort. Sci. $61: 467-471$.

2. Bohn, G. W. and T. W. Whitaker. 1949. A gene for male sterility in the muskmelon (Cucumis melo L.). Proc. Amer. Soc. Hort. Sci. 53 : 309-314.

3. EATON,F.M. 1957. Selective gametocide opens way to hybrid cotton. Science $126: 1174-1175$.

4. HensZ, R.A. and H.C. MoHR. 1959. Functional male sterility in watermelon induced by chemical treatment. Proc. Amer. Soc. Hort. Sci. $74: 552-554$.

5. Hirose, T. 1965. Fundamental studies on the breeding of pepper. Kyoto Prefectural Univ. Tech. Bul. No. 2.
6. JASMIN, J. J. 1954. Male sterility in Solanum melongena L.. Preliminary report on a functional type of male sterility in egg-plants. Proc. Amer. Soc. Hort. Sci. 63 : 443.

7. KHO,Y.O. and J.W.DE BRUYN. 1962. Gametocidal action of dichloroacetic acid. Euphytika 11: $287-292$.

8. LANGE, A.H. 1961. The effect of 2,3-dichloroisobutyrate and 2,2-dichloropropionate on the sex expression of Carica papaya L.. Proc. Amer. Soc. Hort. Sci. $78: 218-224$.

9. LESLEY, J.W. and M.M.LESLEY. 1939. Unfruitfulness in the tomato caused by male sterility. Jour. Agri. Res. $58: 621-630$.

10. LIPPERT,L.F. and M.O.HALL. 1961. Gametocidal action of FW-450 on cantaloupe. Proc. Amer. Soc. Hort. Sci. 78 : 319-323. 
11. Matsuura, R.M. and T.M. Currence. 1962. A male sterile and an early ripening mutant from irradiation of tomato seeds. Proc. Amer. Soc. Hort. Sci. 80 : 515-521.

12. MOORE, J. F. 1959. Male sterility induced in tomato by sodium 2, 3-dichloroisobutyrate. Science 129 : 1738-1740.

13. NAKAMURA, N. 1954. Studies on tle artificial male-sterility. I. Male sterility of egg-plant by chemical pouring. Hyogo Univ. Agri. Sci. Rep. 1 : 111-114.

14. — and M. Terabun. 1955. Studies on the artificial male-sterility II. Male-sterility of cucumber by chemical pouring. Hyogo Univ. Agri. Sci. Rep. $2: 44-46$.

15. _ _ - and S. MaEKAwA. 1960. Studies on the vegetative hybrid of Cucurbitaceae. III. On the male-sterile mutant in cucumber. Hyogo Univ. Agri. Sci. Rep. 4 : 175-178.

16. Peterson,P.A. 1958. Cytoplasmically inherited male sterility in Capsicum. Amer. Nat. 92:
$111-119$.

17. Rенм, S. 1952. Male-sterile plant by chemical treatment. Nature $170: 38-39$.

18. RICK, C. M. 1945. Field identification of genetically male sterile tomato plants for use in producing $F_{1}$ hybrid seed. Proc. Amer. Soc. Hort. Sci. $46: 277-283$.

19. SCOTT,D.H. and M.R.RINER. 1946. Inheritance of male sterility in winter squash. Proc. Amer. Soc. Hort. Sci. $47: 375-377$.

20. ScOTT, R.A. JR. 1957. Biochemical control of anther dehiscence in cotton treated with Dalapon or FW-450. Proc. Cotton Defol. \& Physiol. Conf., Memphis, Tenn. 4-6.

21. 1961. Mechanisms and reversal of gametocide response in cotton. Plant Physiol. $36: 529-538$.

22. WitTwer, S. H. and I. G. Hillyer. 1954. Chemical induction of male sterility in cucurbits. Science $120: 3126$.

\section{化学的処理によるピーマンの除雄に関する研究(第 1 報)}

2 塩化プロピオン酸ソーダの散布によるやくの裂開抑

制と茎葉および花器の形態的变化

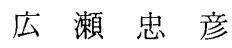

(香川大学農学部)

\footnotetext{
摘 要

ピーマンの $\mathrm{F}_{1}$ 採種に当たってはその除雄操作に多大 の労力を要する。この省力化を目的として 2 壏化プロピ オン酸ソーダの $10,50,250$, および $1250 \mathrm{ppm}$ 水溶液を 葉面散布し，その効果を調べた。供試品種には三重みど りを用い, 1 回散布区と 7 日間隔 3 回散布区とを設け た。250 ppm 3 回散布または $1250 \mathrm{ppm}$ 1回処理によっ てやくは全く黄白化し，裂開は全く押えられた。これら の処理区では開花数はかなり減少したが，茎葉の薬害は 軽微であった。たた，やくの裂開が完全に押えられた花

では花柱の屈曲や子房の肥大などの異常を示すものがか なり見られた。しかし花およびやくの大きさには差異が 垫められなかった。除雄効果は処理後 2 週間めごろから 急に現われ, 以後徐々に減退した。また, やくの裂開が 完全に押えられてもそのやく胞中には発達した花粉粒が 観察された。これらのことから，この薬剤は花粉母細胞 減数分裂期以前のつぼみにその効果を及ぼすものであ り, その場合も花粉粒の発達は大きく阻害せず, やくの 裂開誡能のみを抑止するものと思われる。
} 